\title{
Distinct Roles for B7-1 (CD-80) and B7-2 (CD-86) in the Initiation of Experimental Allergic Encephalomyelitis
}

\author{
Michael K. Racke, *‡ Dorothy E. Scott, ${ }^{5}$ Laura Quigley, * Gary S. Gray, ${ }^{1}$ Ryo Abe, "Carl H. June," and Peter J. Perrin" \\ * Neuroimmunology Branch, National Institute of Neurologic Diseases and Stroke, National Institutes of Health, Bethesda, Maryland \\ 20892; ${ }^{\ddagger}$ Department of Neurology, Washington University School of Medicine, St. Louis, Missouri 63110; ${ }^{\S}$ Food and Drug \\ Administration, Bethesda, Maryland 20892; 'Repligen Corporation, Cambridge, Massachusetts 02139; and "Immune Cell Biology \\ Program, Naval Medical Research Institute, Bethesda, Maryland 20889-5607
}

\begin{abstract}
The activation and differentiation of $T$ cells require both antigen/MHC recognition and costimulatory signals. The present studies examined the role of B7-1 (CD80) and B72 (CD86) costimulation in the prototypic autoimmune disorder, experimental allergic encephalomyelitis (EAE). In adoptively transferred EAE, in vitro activation of myelin basic protein (MBP)-specific lymph node cells was inhibited by the combination of anti-CD80 plus anti-CD86, but not individually. However, in actively induced disease, one injection of anti-CD80 significantly reduced disease, while antiCD86 exacerbated disease. Interestingly, one injection of CTLA-4Ig suppressed disease, while multiple injections resulted in enhanced disease. Thus, the costimulation provided by B7-1 molecules appears to be important for the development of encephalitogenic $T$ cells. The enhanced disease caused by multiple injections of CTLA-4Ig or a single injection of anti-CD86 suggests an inhibitory function for CD86 interaction with its counterreceptors CD28 and CTLA-4 in EAE. Alternatively, these results are consistent with an essential timing requirement for the coordinated interaction of $\mathrm{B} 7$ and CD28 family receptors, and that disruption of this critical timing can have opposing results on the outcome of an immune response. (J. Clin. Invest. 1995. 96:21952203.) Key words: allergic encephalomyelitis • autoimmune disease • B7 • T lymphocyte • T cell costimulation
\end{abstract}

\section{Introduction}

For $\mathrm{T}$ cell activation to take place, it is necessary for the $\mathrm{T}$ cell to receive two signals from the antigen presenting cell (APC) ${ }^{1}$ (1-3). One signal determines the antigen-specificity of the response and results from antigenic peptide bound to MHC interacting with the $\mathrm{T}$ cell receptor. The second signal, termed costimulation, is provided by accessory molecules on the APC

Address correspondence to Dr. Michael K. Racke, Department of Neurology, Washington University School of Medicine, Box 8111, $660 \mathrm{~S}$. Euclid Ave., St. Louis, MO 63110. Phone: 314-362-7968; FAX: 314362-2826; E-mail: rackem@neuro.wustl.edu

Received for publication 6 June 1995 and accepted in revised form 3 August 1995.

1. Abbreviations used in this paper: APC, antigen presenting cell; EAE, experimental allergic encephalomyelitis; LNC, lymph node cells; MBP, myelin basic protein.

The Journal of Clinical Investigation, Inc.

Volume 96, November 1995, 2195-2203 and appears to be necessary for functional T cell activation (4). The B7 family of cell surface molecules expressed on APC is capable of providing this second signal to $\mathrm{T}$ cells via two receptors, CD28 and CTLA-4 $(5,6)$.

Previously, we have examined the role of the B7:CD28/ CTLA-4 interaction in the induction of a prototypic, $T$ cell mediated, autoimmune disorder experimental allergic encephalomyelitis (EAE) (7). EAE is induced by CD4+, class II MHCrestricted $\mathrm{T}$ cells of the Th1 phenotype that predominantly secrete the cytokines IL-2 and IFN- $\gamma(8-10)$. In most murine models of EAE, the response of these encephalitogenic T cells is directed against either of two myelin antigens, MBP or proteolipid protein (11-12). We demonstrated that by using a fusion protein ligand for B7, CTLA-4Ig, we were able to inhibit the proliferation and IL-2 production of MBP-specific LNC during their activation in vitro, resulting in reduced clinical disease upon subsequent transfer (7).

It appears that Th1-like $\mathrm{T}$ cells are the inducing cells in the EAE model (8-10). As we and others have shown, costimulation provided through CD28 is very important for the secretion of cytokines by Th1 cells $(4,7,13)$. On the other hand, Th2 cells, which predominantly secrete IL-4 and IL-10, are helper cells important for IgG1 and IgE antibody production and appear to be important regulatory cells in inflammatory, DTHlike responses, including $\operatorname{EAE}(10,14,15)$. The ability of CD28 to provide costimulation to Th2 cells is less well-defined, although there appear to be examples where B7 may also play a role in IL-4 production $(16,17)$.

At least two members of the $\mathrm{B} 7$ family of CD28 ligands have been defined, B7-1 (CD80) and B7-2 (CD86) (18-24). These molecules, although only having modest homology, are each able to provide costimulation to $\mathrm{T}$ cells for proliferation and $\mathrm{IL}-2$ production $(22,25,26)$. It is probably for this reason, that a mouse genetically deficient for CD80 (B7-1), was essentially immunocompetent (21). In addition, it is likely that there may be another member of the $\mathrm{B} 7$ family capable of providing a costimulatory signal to T cells through CD28 and/or CTLA$4(27,28)$.

B7-1 (CD80) and B7-2 (CD86) may be expressed differentially on various $A P C$ and their kinetics of expression and binding may also differ (24). B7-2 is constitutively expressed by monocytes, however B7-1 can be induced on these APC by IFN$\gamma(20,29,30)$. On B cell populations following an activation stimulus, B7-2 is expressed within $6 \mathrm{hr}$ while B7-1 expression occurs significantly after that time $(27,31,32)$. Interestingly, only B7-2 expression is increased on dendritic cells after exposure to IFN- $\gamma(33)$.

Initial studies indicated that CTLA- 4 provided a costimulatory signal in conjunction with CD28 (34). Recent evidence suggests that the signaling through the CTLA- 4 molecule may 
actually mediate a negative regulatory function. There are several lines of evidence to support this notion. First, in CD28deficient mice, costimulation provided by $\mathrm{B}^{+}$accessory cells did not appear to transduce a positive signal (35). Other studies provided direct evidence for the ability of CTLA- 4 to deliver a negative signal $(36,37)$. Furthermore, constitutive expression of murine B7-1 (CD80) on mature B cells resulted in depressed antibody responses to $\mathrm{T}$ cell-dependent hapten-protein conjugates, suggesting that B7-1 may contribute to feedback inhibition of $\mathrm{T}$ cell-dependent immune responses in vivo (38).

In light of these differences, we examined the separate roles of the different costimulatory molecules B7-1 (CD80) and B72 (CD86) in a T cell-mediated, organ-specific model of autoimmunity, EAE. Our results indicate that antigen (MBP)-primed $T$ lymphocytes are capable of becoming activated and encephalitogenic by in vitro stimulation utilizing either B7 ligand, CD80 or CD86. However, there appears to be differential effects of these ligands on the development of encephalitogenic $T$ cells in vivo, demonstrated by different clinical outcomes when antiB7 reagents are administered in actively induced EAE.

\section{Methods}

Mice. Female SJL/J and $(\mathrm{PL} \times \mathrm{SJL}) \mathrm{F} 1$ mice were obtained from The Jackson Laboratory (Bar Harbor, ME) at 6-8 wk of age. Mice were 10-12 wk of age when experiments were initiated. All procedures were in compliance with guidelines set by the NIH Animal Care and Use Committee.

Reagents. Whole MBP was prepared from guinea pig spinal cords (Rockland, Inc., Gilbertsville, PA) as previously described (39). Human CTLA-4Ig and a control fusion protein hIgG1 were prepared by utilizing a previously described strategy (40). $\alpha \mathrm{CD} 80 \mathrm{mAb} 16-10 \mathrm{~A} 1$ (41) was provided by Dr. Hans Reiser (Dana Farber Cancer Institute, Boston, MA). Anti-murine CD86 mAb GL-1 (23) was provided by Dr. Richard Hodes (National Institute of Aging, NIH, Bethesda, MD). mAb 9.3 was used as a control for $\alpha \mathrm{CD} 80$ and a rat IgG2a antibody was used as a control for $\alpha \mathrm{CD} 86$. All antibodies were purified from hybridoma culture supernatants and the endotoxin content of the hCTLA-4Ig, the control fusion protein, and all $\mathrm{mAb}$ used in these studies was less than $0.4 \mathrm{EU} / \mathrm{mg}$. Fab fragments were made from anti-CD80, anti-CD86, and control antibodies using the ImmunoPure Fab Kit (Pierce, Rockford, IL) according to the manufacturer's instructions. The Fab fragments were subsequently run on a $12 \%$ SDS-PAGE gel under nonreducing conditions with molecular weight markers and whole antibody molecules. Gels were stained with Coomasie blue and purity assessed.

Induction of EAE. For adoptively transferred EAE, SJL mice were immunized with MBP (400 $\mu \mathrm{g})$ in CFA and $10 \mathrm{~d}$ later draining lymph nodes removed. MBP-specific LNC were cultured in RPMI 1640 (Bio Whittaker, Walkersville, MD) supplemented with $10 \%$ FBS, penicillin $\mathrm{G}(100 \mathrm{U} / \mathrm{ml})$, glutamine $(2 \mathrm{mM})$, nonessential aminoacids, Hepes buffer, 2-ME, and MBP ( $25 \mu \mathrm{g} / \mathrm{ml}$ ) for $4 \mathrm{~d}$. LNC were then washed and adjusted to the required concentration in PBS so that each recipient received $3 \times 10^{7}$ cells in a $0.2 \mathrm{ml}$ suspension via the tail vein. Recipient mice were examined daily for signs of disease by a blinded examiner and graded on the following scale: 0 , no abnormality; 1 , a limp tail; 2 , moderate hind limb weakness; 3 , severe hind limb weakness; 4, complete hind limb paralysis; 5 , quadriplegia, or premoribund state (10).

For actively induced EAE, $(\mathrm{PL} \times \mathrm{SJL}) \mathrm{F} 1$ mice were immunized subcutaneously with MBP/CFA ( $400 \mu \mathrm{g} \mathrm{MBP/mouse)} \mathrm{twice} \mathrm{separated}$ by one week. Animals were observed daily for signs of disease as above.

Lymphocyte proliferation. Proliferative responses were measured on MBP-specific LNC by incubating LNC $\left(2 \times 10^{5}\right.$ cells/well $)$ with MBP $(25 \mu \mathrm{g} / \mathrm{ml})$ or medium alone in the presence or absence of the various concentrations of anti-B7 reagents as indicated. For MBP-specific T cell lines, $\mathrm{T}$ cells $\left(1 \times 10^{5}\right.$ cells $/$ well $)$ were cultured with irradiated $(3000$ rad), syngeneic splenocytes as APC $\left(2 \times 10^{5}\right.$ cells/well $)$. T cell lines were generated as previously described (42). Cultures were maintained in 96-well, flat-bottom microtiter plates (Costar, Cambridge, MA) for $96 \mathrm{~h}$ at $37^{\circ} \mathrm{C}$ in humidified $5 \% \mathrm{CO}_{2}$ air. The wells were pulsed with 1 $\mu \mathrm{Ci} /$ well of $\left[{ }^{3} \mathrm{H}\right]$ methyl-thymidine (New England Nuclear, Boston, MA) for the final $16 \mathrm{~h}$ of culture. Cells were harvested on glass fibers and incorporated $\left[{ }^{3} \mathrm{H}\right]$ methyl-thymidine was measured with a Betaplate counter (Wallac, Gaithersburg, MD). Results were determined as arithmetic means from quadruplicate cultures and SEM shown.

Measurement of lymphokine production. An IL-2-dependent cell line, CTLL.EV (43), was generously provided by Dr. W. Paul (National Institute of Allergy and Infectious Diseases, NIH, Bethesda, MD). 50 $\mu \mathrm{l}$ of supernatants from experimental cell cultures were assayed in quadruplicate. Results were compared with proliferation of the cell line to known amounts of IL-2 as standards. Standard deviation of replicate cultures was $<10 \%$ of the mean.

Statistical methods. Treatment effects were assessed by the MannWhitney Sum of Ranks test.

\section{Results}

Effects of anti-B7 reagents on $M B P$-specific T cell proliferation and IL-2 production. Previously, we demonstrated that the presence of CTLA-4Ig during the in vitro activation stage of adoptively transferred EAE resulted in a decreased proliferative response by MBP-specific LNC, reduced IL-2 production, and a diminution of clinical disease on subsequent transfer (7). With antibodies that specifically recognize two members of the B7 family, CD80 (B7-1) and CD86 (B7-2), we were able to examine the ability of these molecules to provide costimulation to MBP-primed LNC. As shown in Fig. 1, neither the presence of $\alpha \mathrm{CD} 80$ nor $\alpha \mathrm{CD} 86$ alone substantially inhibited the proliferative response of MBP-specific LNC to MBP. However, the addition of both $\alpha \mathrm{CD} 80$ plus $\alpha \mathrm{CD} 86$ resulted in dramatic inhibition of $\mathrm{T}$ cell proliferation ( $81 \%$ inhibition at the concentration of $0.625 \mu \mathrm{g} / \mathrm{ml}$ of both antibodies). As we had shown previously, addition of CTLA-4Ig inhibited $\mathrm{T}$ cell proliferation in a dose-dependent manner (Fig. 1). Of note, while increasing the concentration of CTLA-4Ig resulted in decreased proliferation, the combination of $\alpha \mathrm{CD} 80$ and $\alpha \mathrm{CD} 86$ was most efficient at inhibiting $\mathrm{T}$ cell proliferation at the lowest concentration examined. This unexpected dose-response suggested the possibility that signal transduction through the $\mathrm{B} 7$ receptor is induced by the antibodies at lower concentrations, followed by effects consequent to receptor blockade at higher concentrations. To test this possibility, Fab fragments of the $\alpha \mathrm{B} 7$ antibodies were used to examine their effect on $\mathrm{T}$ cell proliferation. Similar to CTLA-4Ig, use of Fab fragments resulted in a dose-dependent inhibition of $\mathrm{T}$ cell proliferation (Fig. $1 \mathrm{C}$ ).

In addition to $\mathrm{T}$ cell proliferation, we also examined the secretion of IL-2 into the tissue culture supernatants (Fig. 2). Since a low concentration of $\alpha \mathrm{CD} 80$ plus $\alpha \mathrm{CD} 86$ was most effective in inhibiting $\mathrm{T}$ cell proliferation, we used these reagents at an optimal concentration of $1 \mu \mathrm{g} / \mathrm{ml}$ when examining IL-2 production. For comparison, CTLA4-Ig was used at a concentration of $5 \mu \mathrm{g} / \mathrm{ml}$. Both the combination of $\alpha \mathrm{CD} 80$ plus $\alpha \mathrm{CD} 86$ or CTLA4-Ig alone inhibited the production of IL-2 by MBP-specific LNC. It is important to note that in our previous study, the dose response for the effect of CTLA-4Ig on IL-2 production by MBP-specific LNC reached a plateau at $5 \mu \mathrm{g} /$ ml, such that IL-2 production was inhibited to a similar degree by CTLA-4Ig when used at a concentration of $30 \mu \mathrm{g} / \mathrm{ml}$ (7).

Because of the decreased proliferative response and reduced 
A

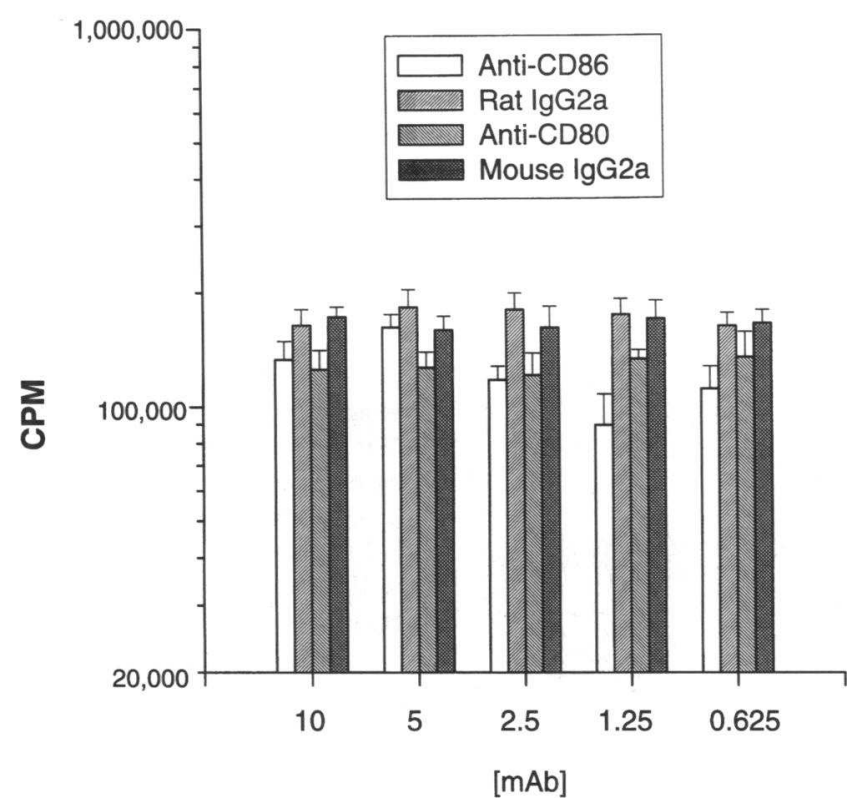

C

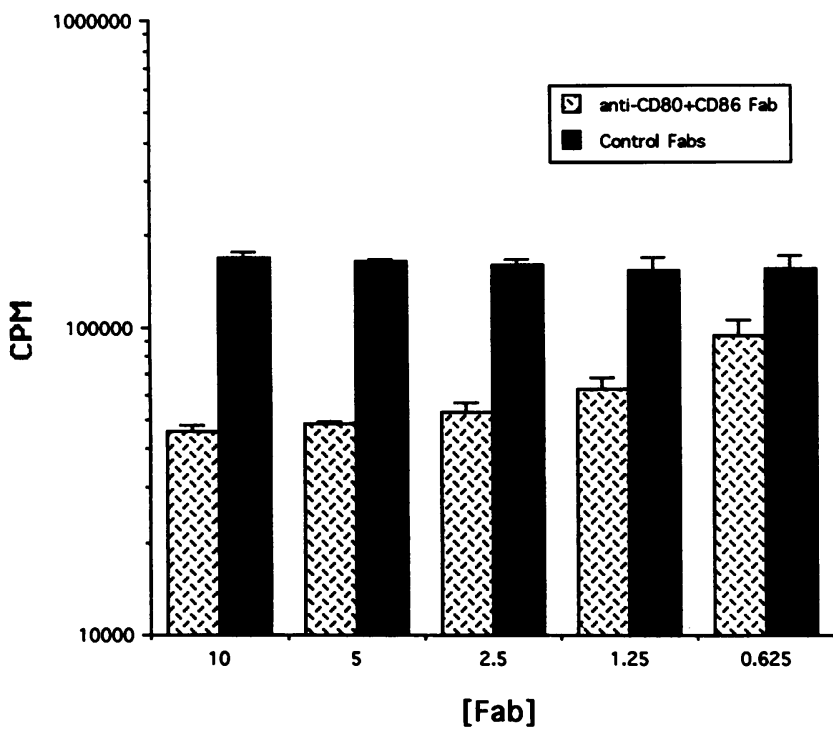

IL-2 production, the proliferative response of the above $T$ cell lines upon restimulation with MBP was examined. Mice were immunized with MBP in the absence of costimulatory blockade, and the draining LNC cultured in the presence of CTLA-4Ig or anti-CD80 plus anti-CD86. Despite reduced IL-2 production in the presence of CTLA-4Ig or $\alpha \mathrm{CD} 80$ plus $\alpha \mathrm{CD} 86$ during the initial stimulation in vitro (Fig. 2), all cell lines responded to MBP restimulation and produced significant amounts of IL-2 (Fig. 3). Addition of CTLA-4Ig during the second stimulation of these lines resulted in no or only modest inhibition $(<25 \%)$ of the proliferation of cells previously activated in the presence of the chimeric IgG1 or CTLA-4Ig (Fig. $3 \mathrm{~A}$ ). The addition of $\alpha \mathrm{CD} 80$ plus $\alpha \mathrm{CD} 86$ during the second stimulation did not significantly inhibit $\mathrm{T}$ cell proliferation ( Fig. $3 B$ ). This suggests that the lack of $\mathrm{B} 7$ costimulation did not tolerize the entire population of MBP-specific T cells. Alternatively, because these

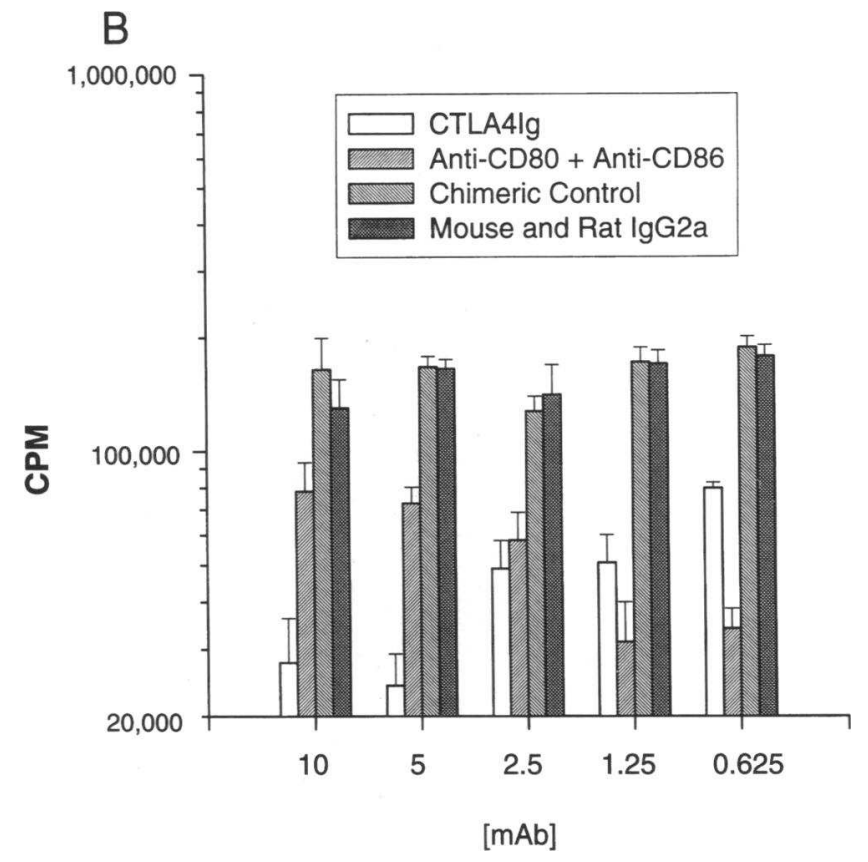

Figure 1. $\alpha \mathrm{CD} 80$ and $\alpha \mathrm{CD} 86$ together, but not individually, suppress proliferation of MBP-primed LNC. SJL/J mice were immunized with MBP/CFA, draining lymph nodes removed $10 \mathrm{~d}$ later, and stimulated in culture medium with MBP (25 $\mu \mathrm{g} / \mathrm{ml})$ as described in Methods. (A) Varying concentrations ( $\mu \mathrm{g} / \mathrm{ml}$ ) of $\alpha \mathrm{CD} 80, \alpha \mathrm{CD} 86$, or appropriate control antibodies were included in culture medium. ( $B$ ) CTLA-4Ig, chimeric IgG1, or combination of $\alpha \mathrm{CD} 80$ and $\alpha \mathrm{CD} 86$ or control antibodies were included in the culture medium. (C) Fab fragments of $\alpha \mathrm{CD} 80$ and $\alpha \mathrm{CD} 86$ or control Fabs were included in the culture medium. Baseline proliferation of LNC cultured in the absence of MBP was $1.2 \pm 0.2 \times 10^{4} \mathrm{cpm}$ and proliferation of LNC with MBP and no antibodies was $17.8 \pm 1.2$ $\times 10^{4} \mathrm{cpm}$; results are expressed as the mean of quadruplicate cultures with SEM shown.

reagents only block $B 7$ interactions with CD28 and CTLA-4, other costimulatory pathways were still intact and able to mediate the induction of MBP-specific T cells $(44,45)$. The B7 blocking reagents were present during the entire 10-d period of culture following the initial antigenic stimulation, in order to prevent costimulation in trans from APC present during this period. It should also be noted that our previous study showed that when CTLA-4Ig was present during both in vivo priming and in vitro culture that subsequent MBP-induced LNC proliferation and IL-2 secretion were essentially completely blocked (7).

The ability of either CTLA-4Ig or $\alpha$ CD80 plus $\alpha$ CD86 to inhibit the proliferative response of long-term MBP-specific T cell lines was also examined. Unlike the marked inhibition seen with MBP-specific LNC, the proliferative response of the T cell lines was only minimally inhibited $(<15 \%$ inhibition, data not 


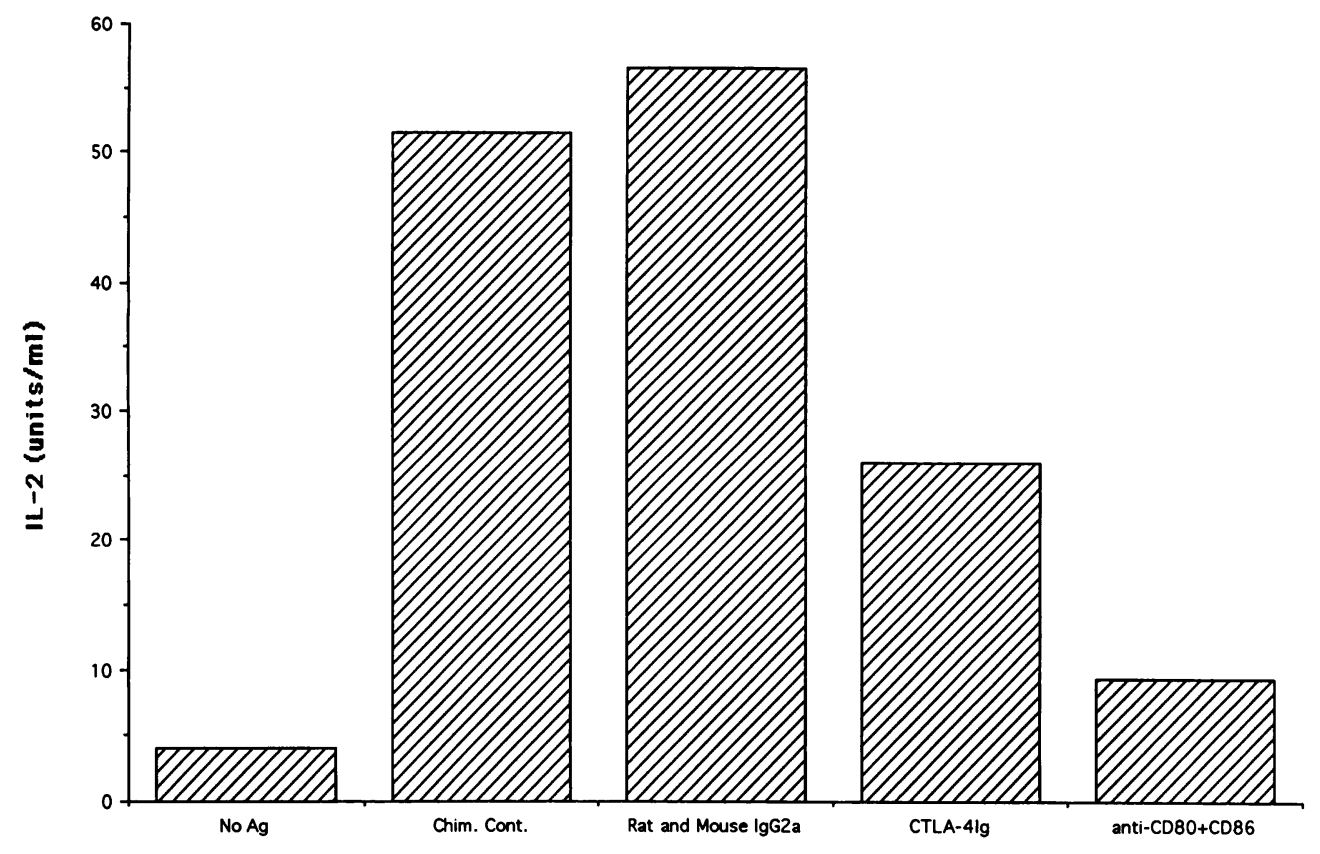

Figure 2. $\alpha \mathrm{CD} 80$ and $\alpha \mathrm{CD} 86$ together suppress IL-2 secretion in cultures of MBP-specific LNC. MBP-specific LNC were obtained as described in Methods and cultured with MBP $(25 \mu \mathrm{g} / \mathrm{ml})$ in the presence of CTLA-4Ig $(5 \mu \mathrm{g} / \mathrm{ml})$, chimeric IgG1 $(5 \mu \mathrm{g} / \mathrm{ml}), \alpha$ CD80 and $\alpha \operatorname{CD} 86(1 \mu \mathrm{g} / \mathrm{ml}$ each $)$, or the appropriate control antibodies. Cells were also cultured in the absence of additional MBP. Supernatants were harvested after $20 \mathrm{~h}$. IL-2 levels were determined using the IL-2-dependent cell line, CTLL.EV. Results are representative of several independent experiments. Carry over of antigen from the in vivo priming accounts for the IL-2 secretion in the no $\mathrm{Ag}$ cultures, as LNC from unprimed In Vitro Culture Treatment mice did not secrete IL-2.
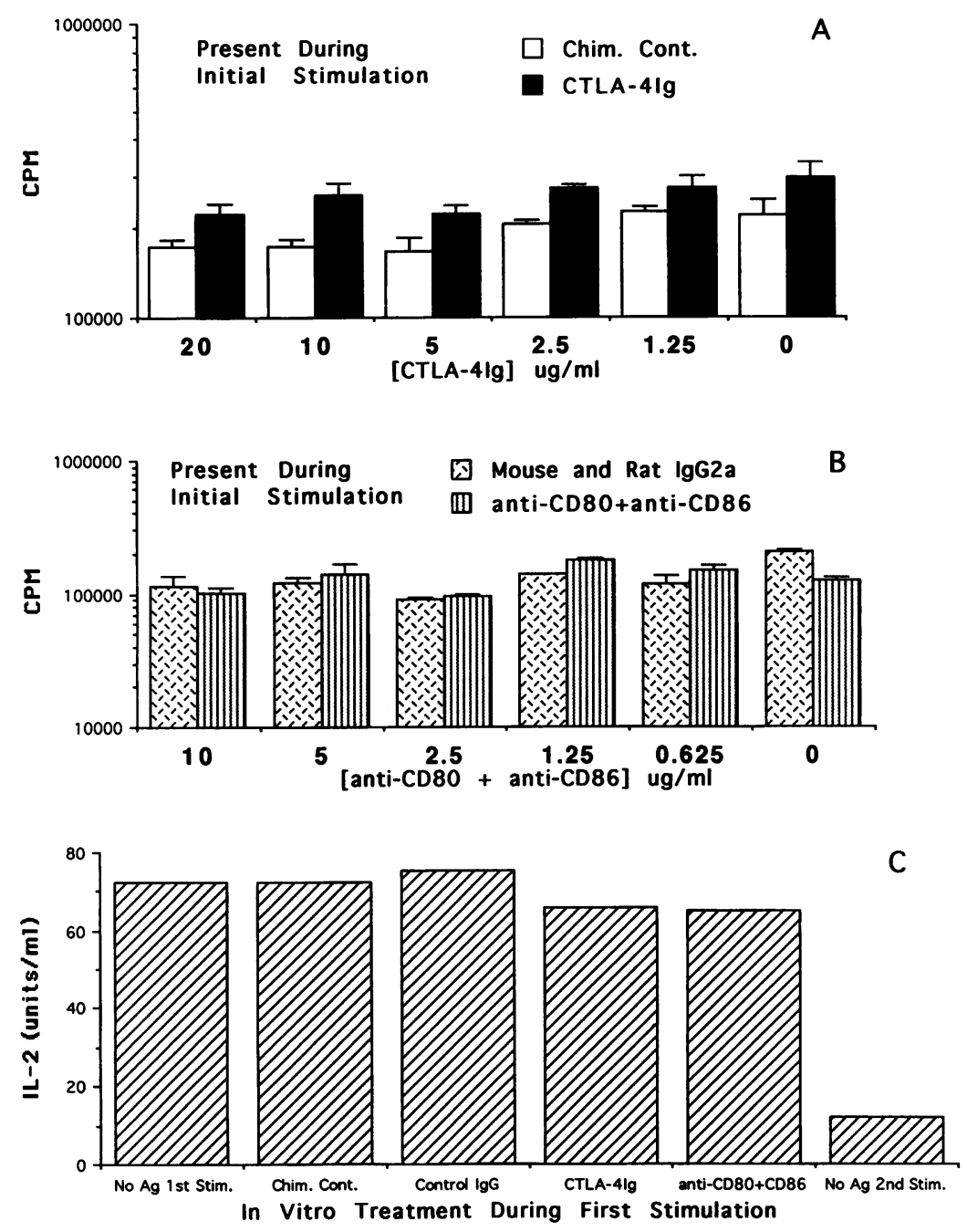

Figure 3. Antigenic restimulation of MBP-specific LNC initially stimulated in the presence of anti-B7 reagents. Mice were primed with MBP in the absence of costimulatory receptor blockade, and draining $\mathrm{LN}$ harvested on day 10. MBP-specific LNC were then stimulated in vitro in the presence of $\alpha \mathrm{CD} 80$ and $\alpha \mathrm{CD} 86$ or CTLA-4Ig as described in Fig. 2. Following the initial stimulation, $\mathrm{T}$ cell lines were cultured with syngeneic, irradiated splenocytes as previously described (42). Cells were cultured with the same concentration of either $\alpha \mathrm{CD} 80$ and $\alpha \mathrm{CD} 86(1 \mu \mathrm{g} / \mathrm{ml})$ or CTLA-4Ig (5 $\mu \mathrm{g} / \mathrm{ml})$ for $10 \mathrm{~d}$. Cell lines were then restimulated with MBP $(25 \mu \mathrm{g})$ $\mathrm{ml}$ ) and various concentrations of anti-B7 reagents. In $A$, MBP-specific LNC initially stimulated in the presence of chimeric IgGl or CTLA-4Ig were restimulated in the presence of MBP and various concentrations of CTLA-4Ig as indicated. In $B$, MBP-specific LNC initially stimulated in the presence of $\alpha \mathrm{CD} 80$ and $\alpha \mathrm{CD} 86$ or control antibodies were restimulated in the presence of MBP and various concentrations of $\alpha \mathrm{CD} 80$ and $\alpha \mathrm{CD} 86$ as indicated. In $A$ and $B$, baseline proliferation of cell lines in the absence of MBP was under $5 \times 10^{3}$ in all cases. In (C), MBP-specific LNC were initially stimulated with MBP in the presence of the following reagents: CTLA-4Ig $(5 \mu \mathrm{g} / \mathrm{ml})$, chimeric IgG1 $(5 \mu \mathrm{g} /$ $\mathrm{ml}), \alpha \mathrm{CD} 80$ and $\alpha \mathrm{CD} 86(1 \mu \mathrm{g} / \mathrm{ml}$ ), or control antibodies. Upon restimulation with MBP, after $20 \mathrm{~h}$, supernatants were harvested and IL-2 levels determined using the CTLL.EV cell line. IL-2 production by cells initially stimulated with MBP in the presence of chimeric IgG1, but not receiving antigenic restimulation is also shown. 

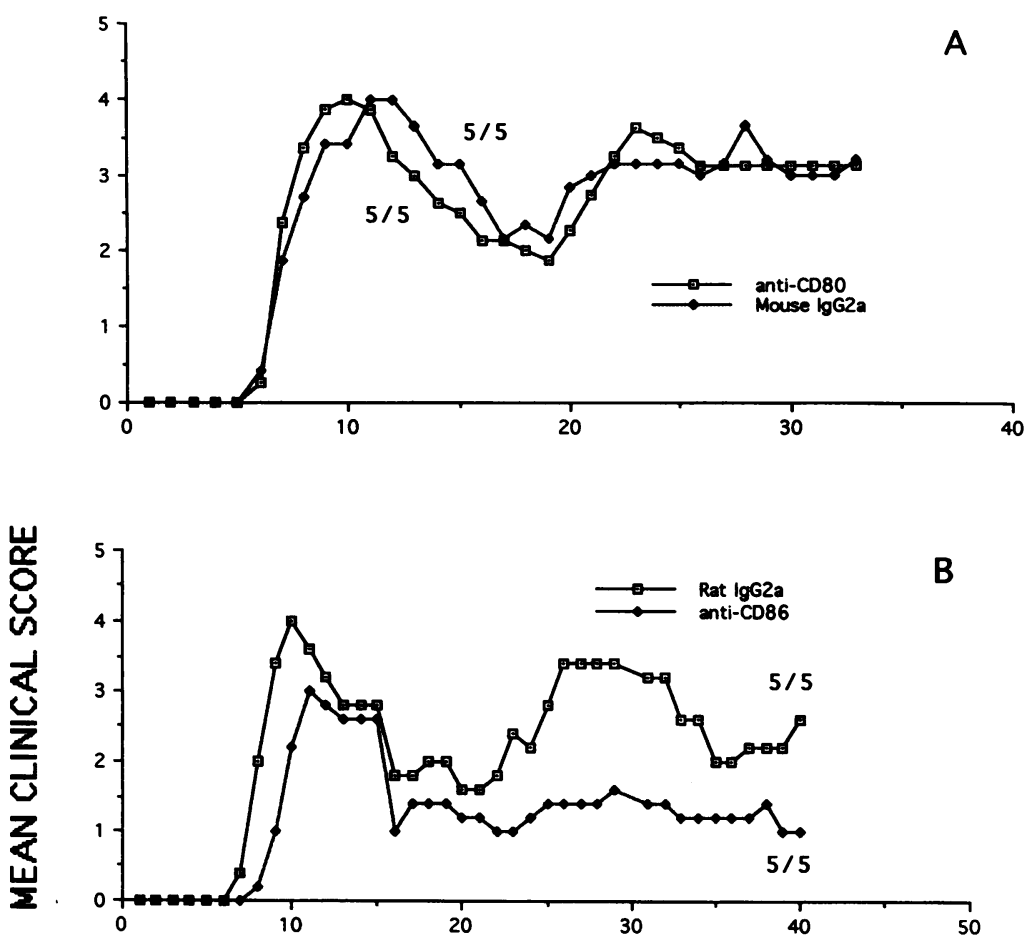

Figure 4. Distinct effects of addition of anti-B7 reagents during in vitro activation of MBP-specific LNC. LNC obtained $10 \mathrm{~d}$ after immunization with MBP/CFA were activated in vitro with MBP $(25 \mu \mathrm{g} / \mathrm{ml})$ and anti-B7

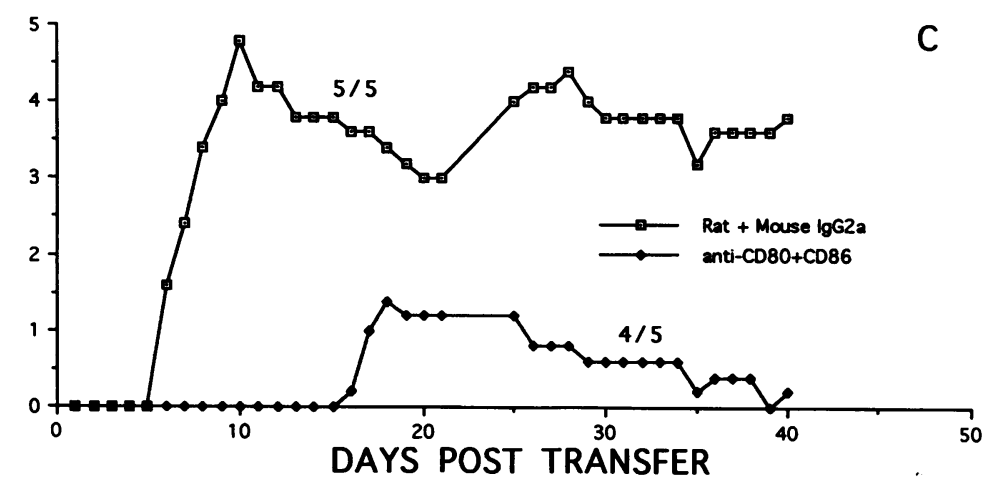
antibodies. LNC were activated in the presence of antiCD80 or mouse IgG2a control mAb $(5 \mu \mathrm{g} / \mathrm{ml})(A)$, anti-CD86 or rat IgG2a control antibody $(5 \mu \mathrm{g} / \mathrm{ml})(B)$, or anti-CD80 plus anti-CD86 or control antibodies ( $\mu \mathrm{g} / \mathrm{ml}$ each) (C). 30 million cells were injected i.v. into naive recipients on day 0 . Mice were examined daily and a mean clinical score was assigned for each group of five mice. In $A$, there was no difference in disease course between the two groups of mice ( $P$ $>0.05$ ). Significant differences between groups were noted in $B$ for days $21-40(P<0.01)$ and in $C$ for days $1-40(P<0.01)$. The incidence of clinical disease during the observation period is indicated next to the corresponding clinical course.

shown). This is consistent with the results above and prior reports suggesting that $\mathrm{B} 7$ costimulation is most important for naive T cells $(46,47)$. Furthermore, these results are consistent with those of others which suggest that the priming of Th2 cells is more dependent upon B7 costimulation than Th1 cells $(16,48)$.

Adoptively transferred EAE with $T$ cells that have been activated in vitro in the presence of $\alpha C D 80$ and/or $\alpha C D 86$. Although either $\alpha \mathrm{CD} 80$ or $\alpha \mathrm{CD} 86$ alone did not inhibit MBPspecific $T$ cell proliferation in vitro, the possibility existed that one of these ligands specifically provided an important costimulatory signal necessary to determine encephalitogenicity. As shown in Fig. 4, the presence of either $\alpha \mathrm{CD} 80$ or $\alpha \mathrm{CD} 86$ alone $(10 \mu \mathrm{g} / \mathrm{ml})$ during the activation of MBP-specific LNC in vitro did not result in a reduction in the severity of transferred EAE during the first episode of disease. Interestingly, while the relapse was quite similar in groups that received anti-CD80 and control antibody (Fig. $4 \mathrm{~A}$ ), the relapse (days $25-35$ posttransfer) was much less severe in mice that received MBP-specific LNC activated in the presence of anti-CD86 (Fig. $4 \mathrm{~B}$ ). However, consistent with the observations in vitro, the presence of both $\alpha \mathrm{CD} 80$ and $\alpha \mathrm{CD} 86$ resulted in a delay in the onset and reduction in the severity of clinical disease (Fig. $4 \mathrm{C}$ ). The near complete abrogation of adoptively transferred EAE in mice receiving cells activated in the presence of anti-CD80 plus antiCD86 is consistent with our previous results observed with CTLA-4Ig (7).

In vivo administration of CTLA-4Ig, $\alpha C D 80$ and/or $\alpha C D 86$ in actively induced EAE. Although both CD80 and CD86 appear to be able to provide costimulation to encephalitogenic $\mathrm{T}$ cells in vitro, because these molecules are differentially regulated on various APC populations, we examined the effect of CTLA-4Ig, $\alpha \mathrm{CD} 80$ and/or $\alpha \mathrm{CD} 86$ on actively induced EAE. For disease induction, a model was chosen where $(\mathrm{PL} \times \mathrm{SJL}) \mathrm{F} 1$ mice were immunized twice with MBP/CFA separated by one week. This regimen was chosen to avoid the confounding effects of pertussis toxin administration on disease induction $(49,50)$.

In our initial experiment, CTLA-4Ig or chimeric control IgG1 was administered every other day for 10 injections ( 100 $\mu \mathrm{g}$ each injection i.p.), beginning the day before the first immunization. As shown in Fig. 5, not only was clinical disease not suppressed, there was a substantial increase in disease from 


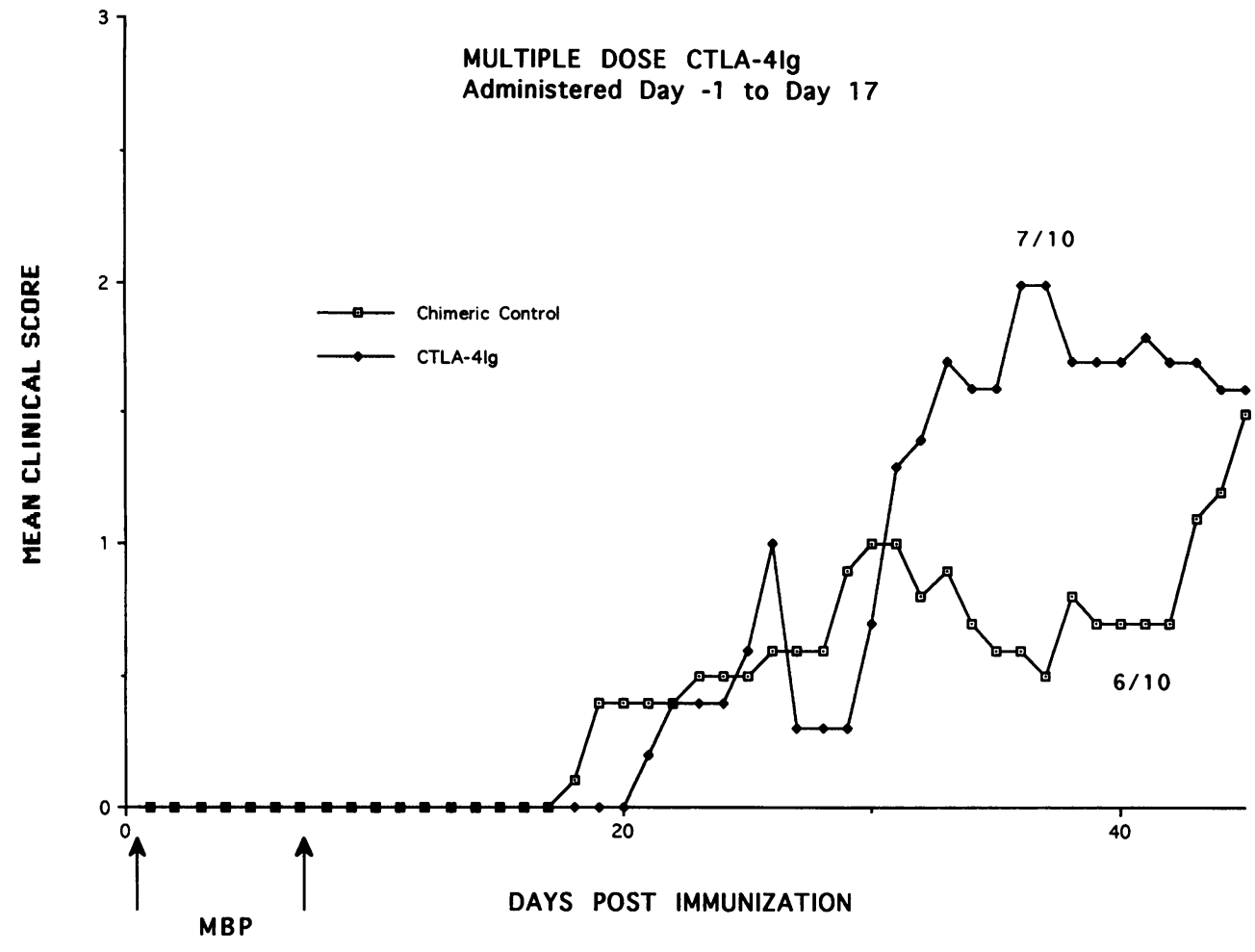

Figure 5. Multiple injections of CTLA-4Ig enhances actively induced EAE. Groups of 10 (PL $\times$ SJL)F1 mice were immunized on day 0 and day 7 with MBP/ CFA (indicated by arrows). Beginning on day -1 , mice received either CTLA-4Ig or chimeric IgG1 $(100 \mu \mathrm{g})$ every other day for a total of 10 injections. Mice were examined daily and a mean clinical score assigned. Comparing the two groups of mice for the entire course of disease, there was no significant difference [days $1-45$, $(P>0.05)]$, however disease was significantly augmented for days $25-45(P<0.01)$. The incidence of clinical disease during the observation period is indicated next to the corresponding clinical course. days $30-45$ postimmunization in the CTLA-4Ig-treated group $(P<0.01)$.

We next examined the effect of one injection of CTLA4Ig, $\alpha \mathrm{CD} 80$ and/or $\alpha \mathrm{CD} 86$ administered $48 \mathrm{hr}$ after the initial immunization. As shown in Fig. $6 A$, a single injection of CTLA-4Ig $(100 \mu \mathrm{g})$ suppressed the first episode of clinical disease, but not the subsequent relapse. On the other hand, one injection of $\alpha \operatorname{CD} 80(100 \mu \mathrm{g}) 48 \mathrm{~h}$ after the primary immunization resulted in almost complete suppression of clinical disease. Conversely, one injection of $\alpha \mathrm{CD} 86$ did not suppress disease, but rather resulted in modest disease exacerbation (Fig. $6 \mathrm{~B}$ ). Finally, administration of both $\alpha \mathrm{CD} 80$ plus $\alpha \mathrm{CD} 86$ resulted in a delay in disease onset and reduced disease severity (Fig. 6 $C$ ), although disease suppression was not as complete as with $\alpha \mathrm{CD} 80$ alone.

\section{Discussion}

In this study, we examined the role of the members of the B7 family, CD80 and CD86, in the prototypic, T cell-mediated, autoimmune disorder, EAE. There were several unexpected observations, the most notable being the unusual dose response of anti-CD80 plus anti-CD86 mAbs for inhibition of MBPinduced costimulation, and the observation that CTLA-4Ig itself can either exacerbate or inhibit disease, depending on the schedule of administration.

First, following in vivo priming of mice with MBP, we asked whether either CD80 (B7-1) or CD86 (B7-2) was predominantly responsible for providing the costimulation for MBP-specific LNC. Neither $\alpha$ CD80 or $\alpha$ CD86 alone significantly inhibited the in vitro proliferative response to MBP (Fig. $1 \mathrm{~A}$ ). Although it has been suggested that CD86 may be the predominant costimulatory molecule in the $\mathrm{B} 7$ family $(6,51$, 52), blocking of either CD80 or CD86 alone had little effect on the proliferative response in vitro. In addition, unlike the dose-dependent inhibition seen with CTLA-4Ig, the combination of $\alpha \mathrm{CD} 80$ plus $\alpha \mathrm{CD} 86$ resulted in the greatest inhibition of proliferation when present at the lowest dose tested. To test whether this observation might be due to signal transduction through the B7 molecules themselves, we repeated the experiment using Fab fragments (Fig. $1 C$ ). Similar to CTLA-4Ig, using the Fab fragments, a dose-dependent inhibition of $T$ cell proliferation was observed, suggesting that the antibodies may be signalling through the B7 receptors. Future experiments will attempt to further define the possibility of signalling through B7 molecules.

We next examined whether there was a difference in the ability of anti-B7 reagents to inhibit the proliferative response of MBP-specific LNC versus T cell lines. Prior studies regarding the activation requirements of naive and memory $\mathrm{T}$ cells in vitro have produced conflicting results. One study demonstrated that naive $T$ cells required a second signal to produce IL-2, while previously primed $\mathrm{T}$ cells needed only peptide-MHC complex stimulation to produce IL-2 (46). Another study reported somewhat similar findings in that memory cells were less dependent than naive cells on accessory cell costimulation (47). In contrast, it has been suggested that dependence on costimulation is related more to the lymphokine secretion profile and less to the T cell's activation state (13). Our results are in agreement with the former observations. Following in vitro stimulation of MBP-primed LNC, restimulation of the MBP-specific T cells was not significantly inhibited $(<25 \%)$ by CTLA-4Ig or the combination of $\alpha \mathrm{CD} 80$ plus $\alpha \mathrm{CD} 86$ (Fig. 2, $A$ and $B$ ). Despite the fact that these encephalitogenic, MBP-specific T cells are of the Th1 phenotype, it appeared that these cells became less dependent on B7 costimulation, presumably due to their prior stimulation in vitro and/or in vivo. Similar observations have been made on the requirement of encephalitogenic $T$ cells for 

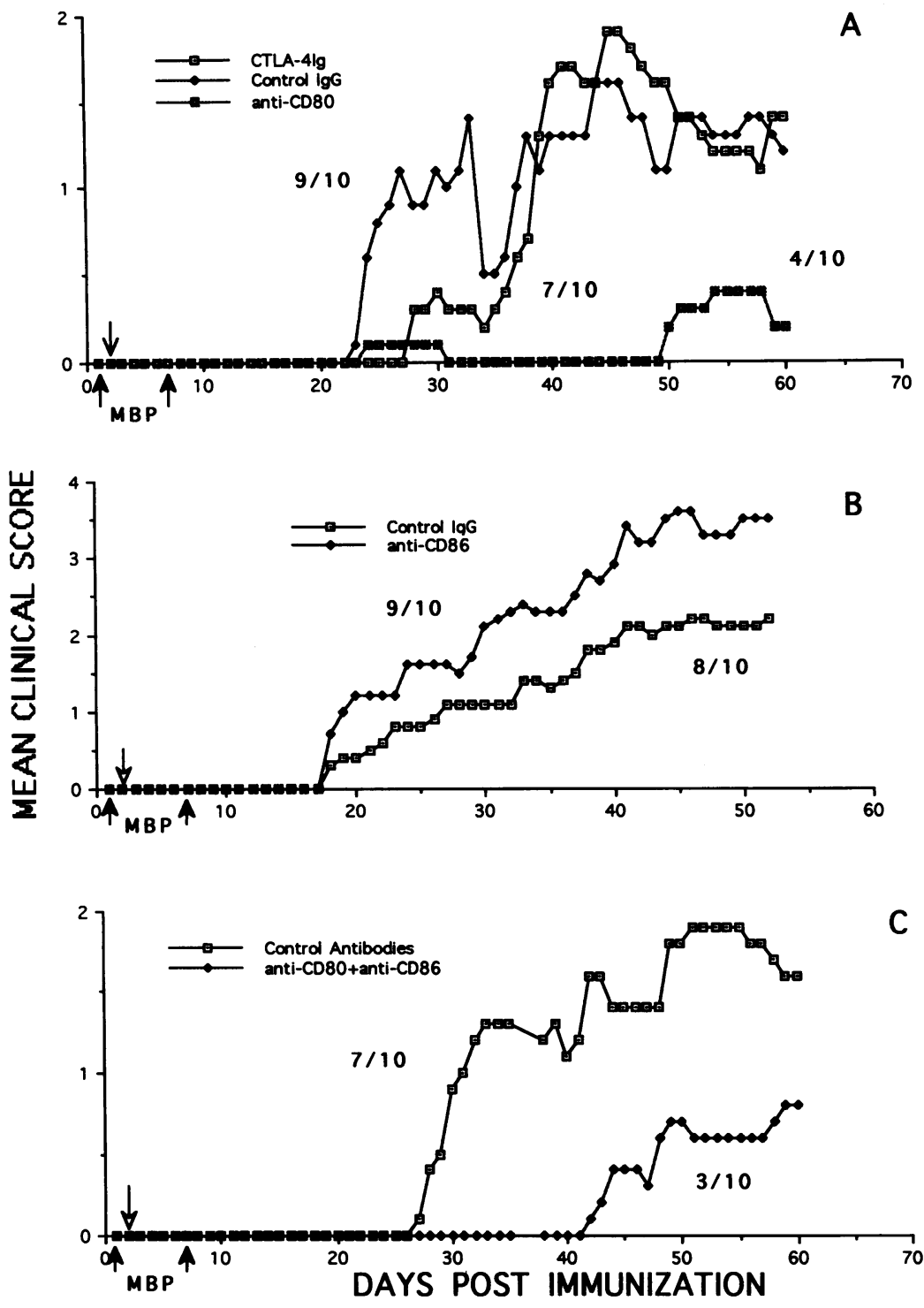

Figure 6. Administration of anti-B7 reagents in actively induced EAE. Groups of ten $(\mathrm{PL} \times \mathrm{SJL}) \mathrm{F} 1$ mice were immunized with MBP/CFA on day 0 and re-immunized $7 \mathrm{~d}$ later (indicated by thick arrows labeled MBP). Two C days after the initial immunization (indicated by thin arrow), mice received an i.p. injection of $100 \mu \mathrm{g}$ of either CTLA-4Ig, anti-CD80 or mouse IgG2a $(A)$, antiCD-86 or rat IgG2a $(B)$, or both anti-CD80 and antiCD86 or control antibodies $(C)$. Mice were examined daily for clinical signs of disease and a mean clinical score assigned. In $A$, significant treatment differences were noted between control IgG and CTLA-4Ig ( $P$ $<0.05)$ and between control IgG and anti-CD80 ( $P$ $<0.01)$. Significant differences were also observed in $B(P<0.05)$ and in $C(P<0.01)$. The incidence of clinical disease during the observation period is indicated next to the corresponding clinical course.

costimulation through the CD4 molecule (53). Lymph node cells sensitized to MBP were much more sensitive to the inhibitory effects of anti-CD4 on their proliferative response than MBP-specific $T$ cell lines, suggesting that $T$ cell lines were less dependent on an interaction through the CD4 molecule. As we had previously demonstrated for CTLA-4Ig (7), the combination of $\alpha \mathrm{CD} 80$ plus $\alpha \mathrm{CD} 86$ during antigenic stimulation in vitro did not result in tolerance induction at the dose used, as upon subsequent antigenic stimulation with MBP these T cells produced IL-2 (Fig. $3 C$ ).

The addition of anti-B7 reagents during the activation of MBP-specific LNC in vitro and in vivo did have differing effects on their encephalitogenicity (Figs. 4 and 6). The presence of $\alpha \mathrm{CD} 80$ during in vitro activation had no effect on subsequent encephalitogenicity. $\alpha \mathrm{CD} 86$ presence during in vitro activation of MBP-specific LNC did not inhibit the initial episode of clinical disease, but animals that received these cells did not develop the severe relapse suffered by animals that had received cells activated in the presence of control antibody. It is possible that a specific population of T cells or APC may be depleted following administration of anti-B7 antibodies. This observation could also be consistent with a model whereby unopposed CD80 costimulation results in a negative signal, and therefore, diminished disease severity. Alternatively, such cells may become insensitive to CD86 costimulation, relying on other pathways, so that subsequent CD86 costimulation does not reactivate these cells. This would be a particularly intriguing possibility in the EAE model, where the extracellular domain of CNS molecules such as myelin-associated glycoprotein and the axonal glycoprotein TAG-1 display homology with the extracellular domain of B7-2 (6). Thus, EAE-inducing cells localized to the CNS might utilize molecules homologous to B7-2. Such a possibility might also suggest that $\alpha$ CD86 might be effective in preventing disease relapses, if such costimulation played a role in reactivating encephalitogenic $\mathrm{T}$ cells.

Because addition of both $\alpha \mathrm{CD} 80$ plus $\alpha \mathrm{CD} 86$ at the doses used did not completely inhibit $\mathrm{T}$ cell encephalitogenicity (Fig. $4 \mathrm{C}$ ), it was possible that the inability to completely inhibit activation was due to costimulation provided by another costimulatory pathway. Alternatively, because of the in vivo priming, these cells were, in fact, no longer naive and required less costimulation. To examine whether in vivo administration of 
CTLA-4Ig could inhibit the in vivo priming of naive lymphocytes, we gave CTLA-4Ig every other day for 10 injections, starting one day before the first immunization in an active model of EAE. Paradoxically, animals that received CTLA-4Ig actually developed more severe disease while consistent with our previous results, a single injection of CTLA-4Ig resulted in substantial clinical protection. Interestingly, transgenic mice that expressed a soluble form of murine CTLA- 4 demonstrated enhanced expansion of antigen-specific CD4+ T cells (54). In that report, animals that received two immunizations separated by one week developed the most dramatic expansion of antigenreactive cells, which is very similar to our model used. This suggested that frequent administration of CTLA-4Ig, or expression of such a transgene, resulted in the use of other costimulatory pathways. Alternatively, the constant presence of CTLA4Ig may prevent the delivery of a subsequent negative signal via $\mathrm{B} 7$ ligands $(36-38,55)$.

To differentiate these possibilities, we performed a series of experiments where we gave only one injection of CTLA4Ig or $\alpha \mathrm{CD} 80$ and/or $\alpha \mathrm{CD} 8648 \mathrm{~h}$. after the initial immunization with MBP. This time point was chosen because this would be when B7-1 expression would be upregulated, but significantly after the peak expression of B7-2. In addition, this time was previously found to be optimal for the induction of allograft tolerance (56). Interestingly, one injection of CTLA-4Ig resulted in inhibition of the first episode of disease, yet subsequent relapses were unaffected (Fig. $6 A$ ) . $\alpha \mathrm{CD} 80$, administered at the time this ligand would be expected to be upregulated, resulted in dramatic inhibition of clinical disease. In contrast, one dose of $\alpha \mathrm{CD} 86$ mildly exacerbated clinical disease. This result is consistent with the recent observation that $\alpha \mathrm{B} 7-1$ administered over several days reduces the incidence of EAE, while $\alpha \mathrm{B} 7-2$ increased disease severity (57).

These results suggest several possibilities. One is that inhibition of CD80's initial costimulation blocked an important factor related to the development of encephalitogenicity. This could include the development of an MBP-specific T cell of the Th1 phenotype, which appears to be necessary to transfer EAE (8, 9 ). Such a possibility has recently been suggested for results in the EAE model (57), however in another model of autoimmune disease, the nonobese diabetic mouse model, $\alpha \mathrm{B} 7-2$ treatment was protective while $\alpha \mathrm{B} 7-1$ accelerated disease (58). This would suggest that the concept that B7-1 costimulation preferentially results in development of Th1 cells, while B7-2 results in the development of Th2 cells may be overly simplistic. Alternatively, allowing certain APC populations to give initial CD86 costimulation, which should be expressed as early as $6 \mathrm{hr}$. after the antigenic stimulus, may activate encephalitogenic precursors through CD28, but then subsequent inhibitory signals which might be delivered through CTLA- 4 may have been blocked by the administration of $\alpha$ CD86 at $48 \mathrm{hr}$. after the initial immunization. Finally, our results suggest that the B7 receptors themselves may transduce signals, given the unusual dose response observed for the inhibition of MBP-induced T cell stimulation. Our results demonstrate that complex costimulatory interactions occur in immunopathologic states such as EAE.

\section{Acknowledgments}

This work is dedicated to the memory of Dale E. McFarlin.

This work was supported in part by NMRDC grant 1413. The views expressed in this article are those of the authors and do not reflect the official policy or position of the Department of the Navy, Department of Defense, or the United States Government. M.K. Racke is a Harry Weaver Neuroscience Scholar of the National Multiple Sclerosis Society (JF-2078-A-2).

\section{References}

1. Mueller, D. L., M. K. Jenkins, and R. H. Schwartz. 1989. Clonal expansion versus functional clonal inactivation: a costimulatory signaling pathway determines the outcome of $\mathrm{T}$ cell antigen receptor occupancy. Annu. Rev. Immunol. 7:445-480.

2. Bretscher, P. 1992. The two-signal model of lymphocyte activation twentyone years later. Immunol. Today. 13:74-76.

3. Jenkins, M. K., and J. G. Johnson. 1993. Molecules involved in T-cell costimulation. Curr. Opin. Immunol. 5:351-367.

4. Williams, I. R., and E. R. Unanue. 1990. Costimulatory requirements of murine Th1 clones: The role of accessory cell-derived signals in responses to anti-CD3 antibody. J. Immunol. 145:85-93.

5. Linsley, P. S., and J. A. Ledbetter. 1993. Role of the CD28 receptor during T cell responses to antigen. Annu. Rev. Immunol. 11:191-212.

6. June, C. H., J. A. Bluestone, L. M. Nadler, and C. B. Thompson. 1994 The B7 and CD28 receptor families. Immunol. Today. 15:321-331.

7. Perrin, P. J., D. Scott, L. Quigley, P. S. Albert, O. Feder, G. S. Gray, R. Abe, C. H. June, and M. K. Racke. 1995. Role of B7:CD28/CTLA-4 in the induction of chronic relapsing experimental allergic encephalomyelitis. J. Immunol. 154:1481-1490.

8. Ando, D. G., J. Clayton, D. Kono, J. L. Urban, and E. E. Sercarz. 1989 Encephalitogenic T cells in the B10.PL model of experimental allergic encephalomyelitis (EAE) are of the Th-1 lymphokine subtype. Cell. Immunol. 124:132143.

9. Baron, J. L., J. A. Madri, N. H. Ruddle, G. Hashim, and C. A. Janeway, Jr. 1993. Surface expression of $\alpha 4$ integrin by CD4 T cells is required for their entry into brain parenchyma. J. Exp. Med. 177:57-68.

10. Racke, M. K., A. Bonomo, D. E. Scott, B. Cannella, A. Levine, C. S Raine, E. M. Shevach, and M. Röcken. 1994. Cytokine-induced immune deviation as a therapy for inflammatory autoimmune disease. J. Exp. Med. 180:1961-1966.

11. Zamvil, S. S., and L. Steinman. 1990. The T lymphocyte in experimental allergic encephalomyelitis. Annu. Rev. Immunol. 8:579-621.

12. Martin, R., H. F. McFarland, and D. E. McFarlin. 1992. Immunological aspects of demyelinating diseases. Annu. Rev. Immunol. 10:153-187.

13. McKnight, A. J., V. L. Perez, C. M. Shea, G. S. Gray, and A. K. Abbas. 1994. Costimulator dependence of lymphokine secretion by naive and activated CD4+ T lymphocytes from TCR transgenic mice. J. Immunol. 152:5220-5225.

14. Mosmann, T. R., and R. L. Coffman, 1989. TH1 and TH2 cells: Different patterns of lymphokine secretion lead to different functional properties. Ann. Rev. Immunol. 7:145-173.

15. Racke, M. K., D. Burnett, S.-H. Pak, P. S. Albert, B. Cannella, C. S Raine, D. E. McFarlin, and D. E. Scott. 1995. Retinoid treatment of experimental allergic encephalomyelitis: IL-4 production correlates with improved disease course. J. Immunol. 154:450-458.

16. Lu, P., X. d. Zhou, S.-J. Chen, M. Moorman, S. C. Morris, F. D. Finkelman, P. Linsley, J. F. Urban, and W. C. Gause. 1994. CTLA-4 ligands are required to induce an in vivo interleukin 4 response to a gastrointestinal nematode. $J$. Exp. Med. 180:693-698.

17. Seder, R. A., R. N. Germain, P. S. Linsley, and W. E. Paul. 1994. CD28mediated costimulation of interleukin 2 (IL-2) production plays a critical role in $\mathrm{T}$ cell priming for IL-4 and interferon $\gamma$ production. J. Exp. Med. 179:299-304.

18. Yokochi, T., R. D. Holly, and E. A. Clark. 1982. Lymphoblastoid antigen (BB-1) expressed on Epstein-Barr virus-activated B cell blasts, B lymphoblastoid lines, and Burkitt's lymphomas. J. Immunol. 128:823-827.

19. Freeman, G. J., A. S. Freedman, J. M. Segil, G. Lee, J. F. Whitman, and L. M. Nadler. 1989. B7, a new member of the Ig superfamily with unique expression on activated and neoplastic B cells. J. Immunol. 143:2714-2722.

20. Azuma, M., D. Ito, H. Yagita, K. Okumura, J. H. Phillips, L. L. Lanier, and C. Somoza. 1993. B70 antigen is a second ligand for CTLA-4 and CD28. Nature (Lond.). 366:76-79.

21. Freeman, G. J., F. Borriello, R. J. Hodes, H. Reiser, K. S. Hathcock, G. Laszlo, A. J. McKnight, J. Kim, L. Du, D. B. Lombard, G. S. Gray, L. M. Nadler, and A. S. Sharpe. 1993. Uncovering of functional alternative CTLA-4 counterreceptor in B7-deficient mice. Science (Wash. DC). 262:907-909.

22. Freeman, G. J., J. G. Gribben, V. A. Boussiotis, J. W. Ng, V. A. Restivo, Jr., L. A. Lombard, G. S. Gray, and L. M. Nadler. 1993. Cloning of B7-2: A CTLA-4 counter-receptor that costimulates human $\mathrm{T}$ cell proliferation. Science (Wash. DC). 262:909-911.

23. Hathcock, K. S., G. Laszlo, H. B. Dickler, J. Bradshaw, P. Linsley, and R. J. Hodes, 1993. Identification of an alternative CTLA-4 ligand costimulatory for T cell activation. Science (Wash. DC). 262:905-907.

24. Linsley, P. S., J. I. Greene, W. Brady, J. Bajorath, J. A. Ledbetter, and 
R. Peach. 1994. Human B7-1 (CD80) and B7-2 (CD86) bind with similar avidities but distinct kinetics to D28 and CTLA-4 receptors. Immunity. 1:793-801.

25. Freeman, G. J., F. Borriello, R. J. Hodes, H. Reiser, J. G. Gribben, J. W Ng, J. Kim, J. M. Goldberg, K. Hathcock, G. Laszlo, L. A. Lombard, S. Wang G. S. Gray, L. M. Nadler, and A. H. Sharpe. 1993. Murine B7-2, an alternative CTLA4 counter-receptor that costimulates $\mathrm{T}$ cell proliferation and interleukin 2 production. J. Exp. Med. 178:2185-2192.

26. Levine, B. L., Y. Ueda, N. Craighead, M. L. Huang, and C. H. June. 1995. Anti-CD28 antibody and ligands CD80 and CD86 induce long term autocrine growth of CD4+ $\mathrm{T}$ cells and induce similar patterns of cytokine secretion in vitro. Int. Immunol. In press.

27. Boussiotis, V. A., G. J. Freeman, J. G. Gribben, J. Daley, G. Gray, and L. M. Nadler. 1993. Activated human B lymphocytes express three CTLA-4 counterreceptors that costimulate T-cell activation. Proc. Natl. Acad. Sci. USA. 90:11059-11063.

28. Inobe, M., P. S. Linsley, J. A. Ledbetter, Y. Nagai, M. Tamakoshi, and T. Uede. 1994. Identification of an alternatively spliced form of the murine homologue of B7. Biochem. Biophys. Res. Commun. 200:443-449.

29. Freedman, A. S., G. J. Freeman, K. Rhynhart, and L. M. Nadler. 1991. Selective induction of B7/BB-1 on interferon- $\gamma$ stimulated monocytes: A potentia mechanism for amplification of T cell activation. Cell. Immunol. 137:429-437.

30. Nozawa, Y., E. Wachi, K. Tominaga, M. Abe, and H. Wakasa. 1993. A novel monoclonal antibody (FUN-1) identifies an activation antigen in cells of the B-cell lineage and Reed-Sternberg cells. J. Pathol. 169:309-315.

31. Lenschow, D. J., G. H.-T. Su, L. A. Zuckerman, N. Nabavi, C. L. Jellis, G. S. Gray, J. M. Miller, and J. A. Bluestone. 1993. Expression and functional significance of an additional ligand for CTLA-4. Proc. Natl. Acad. Sci. USA. 90:11054-11058.

32. Hathcock, K. S., G. Laszlo, C. Pucillo, P. Linsley, and R. J. Hodes. 1994 Comparative analysis of B7-1 and B7-2 costimulatory ligands: expression and function. J. Exp. Med. 180:631-640.

33. Larsen, C. P., S. C. Ritchie, R. Hendrix, P. S. Linsley, K. S. Hathcock R. J. Hodes, R. P. Lowry, and T. C. Pearson. 1994. Regulation of immunostimulatory function and costimulatory molecule (B7-1 and B7-2) expression on murine dendritic cells. J. Immunol. 152:5208-5219.

34. Linsley, P. S., J. L. Greene, P. Tan, J. Bradshaw, J. A. Ledbetter, C Anasetti, and N. K. Damle. 1992. Coexpression and functional cooperation of CTLA-4 and CD28 on activated T lymphocytes. J. Exp. Med. 176:1595-1604.

35. Green, J. M., P. J. Noel, A. I. Sperling, T. L. Walunas, G. S. Gray, J. A. Bluestone, and C. B. Thompson. 1994. Absence of B7-dependent responses in CD28-deficient mice. Immunity. 1:501-508.

36. Walunas, T. L. D. J. Lenschow, C. Y., Bakker, P. S. Linsley, G. J. Freeman, J. M. Green, C. B. Thompson, and J. A. Bluestone. 1994. CTLA-4 can function as a negative regulator of $T$ cell activation. Immunity. 1:405-413.

37. Gribben, J. G., G. J. Freeman, V. A. Boussiotis, P. Rennert, C. L. Jellis, E. Greenfield, M. Barber, V. A. Restivo, Jr., X. Ke, G. S. Gray, and L. M. Nadler. 1995. CTLA4 mediates antigen-specific apoptosis of human T cells. Proc. Natl. Acad. Sci. USA. 92:811-815.

38. Sethna, M. P., L. V. Parijs, A. H. Sharpe, A. K. Abbas, and G. J. Freeman 1994. A negative regulatory function of $B 7$ revealed in B7-1 transgenic mice. Immunity. 1:415-421.

39. Deibler, G. E., R. E. Martenson, and M. W. Kies. 1972. Large scale preparation of myelin basic protein from central nervous system tissue of several mammalian species. Prep. Biochem. 2:139-165.

40. Gimmi, C. D., G. J. Freeman, J. G. Gribben, G. Gray, and L. M. Nadler. 1993. Human $T$ cell clonal anergy is induced by antigen presentation in the absence of B7 costimulation. Proc. Natl. Acad. Sci. USA. 90:6586-6590.

41. Razi-Wolf, Z., F. Galvin, G. Gray, and H. Reiser. 1993. Evidence for an additional ligand, distinct from B7, for the CTLA-4 receptor. Proc. Natl. Acad. Sci. USA. 90:11182-11186.

42. McCarron, R. M., M. Racke, M. Spatz, and D. E. McFarlin. 1991. Cerebra vascular endothelial cells are effective targets for in vitro lysis by encephalitogenic T lymphocytes. J. Immunol. 147:503-508.

43. Yoshimoto, T., and W. E. Paul. 1994. CD4pos, NK1.1pos T cells promptly produce interleukin 4 in response to in vivo challenge with anti-CD3. J. Exp. Med. 179:1285-1295.

44. van Seventer, G. A., Y. Shimuzu, and S. Shaw. 1991. Roles of multiple accessory molecules in T-cell activation. Curr. Opin. Immunol. 3:294-303.

45. Damle, N. K., K. Klussman, P. S. Linsley, and A. Aruffo. 1992. Differential costimulatory effects of adhesion molecules B7, ICAM-1, LFA-3, and VCAM 1 on resting and antigen-primed CD4+ T lymphocytes. J. Immunol. 148:19851992.

46. Sagerstrom, C. G., E. M. Kerr, J. P. Allison, and M. M. Davis. 1993 Activation and differentiation requirements of primary $\mathrm{T}$ cells in vitro. Proc. Natl. Acad. Sci. USA. 90:8987-8991.

47. Croft, M., L. M. Bradley, and S. L. Swain. 1994. Naive versus memory CD4 T cell response to antigen: Memory cells are less dependent on accessory cell costimulation and can respond to many antigen-presenting cell types including resting B cells. J. Immunol. 152:2675-2685.

48. Corry, D. B., S. L. Reiner, P. S. Linsley, and R. M. Locksley. 1994 Differential effects of blockade of CD28-B7 on the development of Th1 or Th2 effector cells in experimental leishmaniasis. J. Immunol. 153:4142-4148.

49. Kamradt, T., P. D. Soloway, D. L. Perkins, and M. L. Gefter. 1991 Pertussis toxin prevents the induction of peripheral $\mathrm{T}$ cell anergy and enhances the $T$ cell response to an encephalitogenic peptide of myelin basic protein. $J$. Immunol. 147:3296-3302.

50. Yong, T., G. A. Meininger, and D. S. Linthicum. 1993. Enhancement of histamine-induced vascular leakage by pertussis toxin in SJL/J mice but not Balb/ c mice. J. Neuroimmunol. 45:47-52.

51. Caux, C., B. Vanbervliet, C. Massacrier, M. Azuma, K. Okumura, L. L. Lanier, and J. Banchereau. 1994. B70/B7-2 is identical to CD86 and is the major functional ligand for CD28 expressed on human dendritic cells. J. Exp. Med. 180:1841-1847

52. Inaba, K., M. Witmer-Pack, M. Inaba, K. S. Hathcock, H. Sakuta, M. Azuma, H. Yagita, K. Okumura, P. S. Linsley, S. Ikehara, S. Muramatsu, R. J. Hodes, and R. M. Steinman. 1994. The tissue distribution of the B7-2 costimulator in mice: abundant expression on dendritic cells in situ and during maturation in vitro. J. Exp. Med. 180:1849-1860.

53. Mannie, M. D., J. Morrison-Plummer, and T. J. McConnell. 1993. Differentiation of encephalitogenic $\mathrm{T}$ cells confers resistance to an inhibitory anti-CD4 monoclonal antibody. J. Immunol. 151:7293-7306.

54. Ronchese, F., B. Hausmann, S. Hubele, and P. Lane. 1994. Mice transgenic for a soluble form of murine CTLA-4 show enhanced expansion of antigenspecific CD4+ T cells and defective antibody production in vivo. J. Exp. Med. 179:809-817.

55. Jenkins, M. K. 1994. The ups and downs of T cell costimulation. Immunity. $1: 443-446$

56. Lin, H., S. F. Bolling, P. S. Linsley, R. Q. Wei, D. Gordon, C. B. Thompson, and L. A. Turka. 1993. Long-term acceptance of major histocompatibility mismatched cardiac allografts induced by CTLA4Ig plus donor-specific transfusion. J. Exp. Med. 178:1801-1806.

57. Kuchroo, V. K., M. P. Das, J. A. Brown, A. M. Ranger, S. S. Zamvil, R. A. Sobel, H. L. Weiner, N. Nabavi, and L. H. Glimcher. 1995. B7-1 and B7-2 costimulatory molecules activate differentially the Th1/Th2 developmental pathways: Application to autoimmune disease therapy. Cell. 80:707-718.

58. Lenschow, D. J., S. C. Ho, H. Sattar, L. Rhee, G. Gray, N. Nabavi, K. C Herold, and J. A. Bluestone. 1995. Differential effects of anti-B7-1 and anti-B72 monoclonal antibody treatment on the development of diabetes in the nonobese diabetic mouse. J. Exp. Med. 181:1145-1155. 